\title{
A Importância da Criança Escravizada e seu Comércio no Oeste Paulista, 1861-1869
}

\author{
Gabriel Almeida Antunes Rossini ${ }^{1}$
}

\begin{abstract}
Resumo
Neste artigo, lançamos luz sobre a importância da criança escrava no âmbito da expansão cafeeira paulista. Para tanto, além de resgatarmos parte da bibliografia relevante sobre o tema, mobilizamos dados secundários e ampla base de dados primários decorrente de escrituras de compra e venda de escravos compulsadas em importante centro cafeicultor do Oeste paulista, Rio Claro, entre 1861 e 1869. Por meio da bibliografia consultada e dos dados levantados, buscamos apreender a relevância da criança cativa e aspectos econômicos e demográficos atinentes à dinâmica do tráfico interno deste grupo, tais como: volume de transações de compra e venda ocorridas ao longo do recorte temporal eleito; dinâmica do preço de venda; a interação entre preços e sexo, idade, tipologia do comércio doméstico e experiência/ocupação; volume de crianças transacionadas individualmente ou no interior de grupos de escravos; a participação de famílias escravas no âmbito do conjunto das negociações que tivemos acesso.
\end{abstract}

\begin{abstract}
In this article, we shed light on the importance of the slave child in the ambit of the coffee expansion in São Paulo. Therefore, in addition to recovering part of the relevant bibliography on the subject, we mobilized secondary data and a large primary database resulting from deeds of purchase and sale of certified slaves in an important coffee-growing center in the State of São Paulo (Rio Claro), from 1861 to 1869. We sought to understand the relevance of the captive child and economic and demographic aspects related to the dynamics of the internal trafficking of this group, such as: volume of purchase and sale transactions occurring over the time period elected; dynamics of the sale price; the interaction between prices and sex, age, typology of domestic trade and experience / occupation; volume of children transacted individually or within groups of slaves; the participation of slave families in the scope of the negotiations we had access to.
\end{abstract}

\section{Palavras-Chave}

Escravidão. Crianças. Tráfico de Escravos. Brasil - São Paulo. Século XIX.

1 Professor - Universidade Federal do ABC (UFABC) - Endereço: Alameda da Universidade, 3 Anchieta - São Bernardo do Campo/SP - CEP: 09606-070 - E-mail: gabriel.rossini@ufabc.edu.br ORCiD: https://orcid.org/ 0000-0003-0701-8986

Recebido: 01/02/2019. Aceite: 29/05/2019.

(c) (i) (\$) Esta obra está licenciada com uma Licença Creative Commons Atribuição-Não Comercial 4.0 Internacional. 


\section{Keywords}

Slavery. Children. Slaves traffic. Brazil - São Paulo. XIX century.

\section{JEL Classification}

N3.

\section{Introdução}

Os interesses vinculados ao café que estavam em jogo no sudeste do Brasil, nas primeiras décadas do século XIX, tornaram-se tão fortes que fizeram o governo brasileiro negligenciar a Lei Feijó de $1831^{1}$ e as pressões da diplomacia inglesa e admitir o contrabando de escravos que possibilitou os braços necessários à marcha ascendente da cafeicultura pelo Vale do Paraíba fluminense e paulista, pelo sul de Minas Gerais, Espírito Santo e, posteriormente, pelo Oeste-paulista. ${ }^{2}$ Como é sobejamente conhecido, a economia escravista cafeeira no Brasil foi alimentada pelo tráfico transatlântico de escravos até $1850,{ }^{3}$ quando o quadro criado pelo aumento e maior eficácia da repressão inglesa, a maior centralização do aparato estatal do Império do Brasil e o grande volume de escravos importados, ao longo da primeira metade do século XIX, possibilitaram uma nova e efetiva legislação repressora do comércio transatlântico de escravos para o Brasil

${ }^{1}$ Lei Feijó, de 07 de novembro de 1831, foi a primeira lei nacional a proibir o comércio de escravos que se tornou sinônimo de pirataria - e considerou livres todos os africanos introduzidos no Brasil a partir da data da sua promulgação. A despeito dos seus efeitos, a lei foi continuamente contornada. Conhecida vulgarmente como "lei para inglês ver", ela tem sido recorrentemente estudada desde o começo dos anos 2000. "A legislação não só não teve a intenção de enganar os ingleses, como foi pivô de vários embates políticos e jurídicos e esteve no centro do debate sobre a legalidade da escravidão brasileira no século XIX." (Mamigonian e Grinberg 2018). Ver também: Bethell (2002); Azevedo (1999 e 2010); Parron (2007); Chalhoub (2012).

2 Na literatura correlata, o Oeste paulista não corresponde ao oeste geográfico, mas sim à região "que se abre em leque desde Campinas para o Noroeste, alcançando a cidade de Rio Claro e se estendendo até Bauru e Ribeirão Preto" (Dean 1977, 13). Trata-se de região menos montanhosa, com grandes extensões de terra roxa, o que possibilitava índices de produtividade cerca de cinco vezes maiores do que os verificados no Vale do Paraíba. (Cano 1983, 32). Ver também: Cano (1985), Costa (2002) e Furtado (1972). O café pautou a dinâmica econômica brasileira durante o século XIX. Na década de $1820,18,6 \%$ das exportações do país. Na década seguinte, atingiu 43,8\% das exportações do Brasil. Nos anos 1880, alcançou 61,7\% das exportações nacionais (Salles, 2018).

3 Para conhecermos a dimensão e importância do tráfico transatlântico de escravos ver: David Eltis, Um breve resumo do tráfico de escravos transatlântico, In Viagens: Banco de Dados do Tráfico Transatlântico de Escravos, Disponível em: http://www.slavevoyages.org/assessment/essay. Acessado em $\underline{15 / 01 / 2019}$ e Alencastro (2018). 
(Costa 1997). ${ }^{4}$ Tal embargo acarretou copiosos resultados, tais como: alta abrupta e consistente do preço dos escravos; ladinização dos cativos; diminuição da população cativa, pois as mortes superavam os nascimentos; dinamização do tráfico interno de escravos (os deslocamentos ocorriam, sobretudo, das zonas urbanas e rurais menos prósperas para as zonas cafeeiras mais produtivas do sudeste do Império); desmantelamento mais recorrente das famílias escravas, em virtude das vendas de um ou alguns indivíduos do grupo. ${ }^{5}$

A partir do cenário formado pelo fim do tráfico transatlântico de escravos, o presente artigo procura lançar luz sobre a importância da criança escrava e a dinâmica do comércio doméstico de cativos, porém, não do comércio interno de pessoas escravizadas em geral, ${ }^{6}$ mas sim de ramo específico desse mercado. Neste texto, privilegiamos o estudo da dinâmica do tráfico de crianças escravas.

\subsection{A Criança Escrava}

Consideramos a criança escrava como aquela com até 14 anos de idade. Isso se justifica em virtude de algumas pesquisas anteriores indicarem, de forma geral, que o intervalo etário entre 12 e 14 anos correspondia ao período de passagem dos escravos para a vida adulta.

Kátia Mattoso, por meio de inventários post-mortem e testamentos, distinguiu duas infâncias para os escravos: dos zero aos sete para oito anos, as crianças cativas normalmente não desempenhavam atividade econômica, ${ }^{7}$ mas a vida dos folguedos infantis era curta, dos sete para os oito anos até os doze anos de idade, os jovens escravos deixavam de ser crianças para iniciarem a sua entrada, ainda na qualidade de aprendizes, no mundo dos adultos. Segundo Mattoso, as faixas etárias aludidas foram corrobo-

4 O processo de fim do tráfico transatlântico de escravos é recuperado por Araujo (2018).

5 Sobre diversos aspectos da história e historiografia da escravidão no Brasil oitocentista ver: Marquese e Salles (2016).

6 Sobre o tráfico interno de escravos, ver, dentre outros: Klein (1971), Slenes (1976 e 2004), Conrad (1978), Graham (2002), Motta (2012), Scheffer, 2012, Rossini (2015). Ver também: Azevedo (1987), Machado (2010) e Luna \& Klein (2010).

7 Mott (1988, p. 61) diminui esta idade para 5-6 anos. 
radas por documentos oficiais presentes na legislação civil e eclesiástica. Como afirma a autora, "é por demais conhecido que, para a Igreja, a idade de razão de todo o cristão jovem situa-se aos 7 anos de idade, idade de consciência e de responsabilidade. Para a Igreja, aos sete anos a criança adquire foro de adulto: de ingênuo torna-se alma de confissão" (Mattoso 1979, 42). Por seu turno, a parte relativa ao direito civil do Código Filipino, que vigorou durante todo o século XIX, estipulava a maioridade aos 12 anos para as meninas e aos 14 anos para os meninos (Idem).

Ademais, o recorte etário que adotamos também resulta da promulgação de um decreto de 1869 (que abordaremos à frente) e em decorrência de alguns autores hodiernos estabelecerem a primeira faixa etária dos grupos de escravos que estudaram como sendo formada por indivíduos com idade de zero a 14 anos completos. ${ }^{8}$

Outrossim, é certo que outros critérios para além do etário foram utilizados em diferentes momentos e lugares para definirem a criança escrava. Por exemplo, no âmbito dos tráficos de cativos britânico e francês, o critério de altura (cerca $1,30 \mathrm{~m}$ ) distinguia adultos de crianças. No decorrer do século XIX, os negreiros capturados, principalmente provenientes do Brasil e da Espanha, eram registrados por tribunais britânicos e internacionais, e nessas instituições a distinção entre adultos e crianças era a maturidade sexual decorrente da aparência física - o que, diga-se de passagem, poderia variar de acordo com a dieta prevalecente nas áreas onde os africanos foram escravizados (Eltis 2010).

De forma geral importa termos em vista que os critérios adotados para distinguir as crianças dos adultos são imprecisos, pois até mesmo uma definição pautada pela idade dependia de uma avaliação feita por traficantes de escravos, pois muitas culturas africanas não davam importância para esse aspecto.

8 Mattoso (1988), Karash (2000), Motta e Marcondes (2000), Flausino (2006), Motta (2012), Hogerzeil, Simon J. e Richardson, David (2007) e Valencia Villa e Florentino (2016). 


\subsection{Aspectos da Literatura sobre a Criança Escrava}

A despeito de a bibliografia sobre a escravidão ter abordado aspectos atinentes às relações estabelecidas entre senhores e escravos, ao tráfico transatlântico e doméstico de seres humanos em geral, à família, à cultura e à identidade escravas, os estudos sobre a acuidade e a dinâmica específica do comércio de crianças cativas ainda são escassos. Não obstante essa carência, algumas pesquisas publicadas principalmente a partir de fins da década de 1980 começaram a indicar a importância da criança escrava.

Maria Lúcia B. Mott, em Ser mãe: a escrava em face do aborto e do infanticídio, argumenta que as crianças escravas ocuparam lugar relevante no sistema escravista, sobretudo as com mais de cinco anos, quando a taxa de mortalidade caía consideravelmente, seja pelo preço inferior que possuíam - o que possibilitava que fossem adquiridas por pessoas remediadas, seja pela perspectiva de vida longa, pela expectativa de venda futura ou possibilidade de iniciar, desde cedo, o aprendizado de algum ofício exigente de maior destreza - em Rio Claro, ao longo dos anos 1861-1869, como veremos à frente, $93 \%$ das crianças comerciadas sozinhas tinham mais de 5 anos. Além disso, a autora chama a atenção para a existência de tarefas exercidas precipuamente por crianças, tais como: ajudar na lavoura (auxiliar no plantio e colheita, tirar ervas daninhas, semear frutas, cuidar dos animais); buscar água no poço; levar e trazer recados; buscar o jornal e o correio nas vilas e cidades próximas; fazer compras; preparar os cavalos; vender quitutes e outras coisas pelas ruas; engraxar sapatos; escovar as roupas; servir a mesa; espantar mosquitos; balançar a rede; abanar o fogo; carregar diversas coisas; servir como ama-seca ou criada/o, arrumar a casa, ajudar a vestir, desvestir e a banhar as pessoas da casa e os visitantes (Mott, 1989). ${ }^{9}$

Ainda com relação às ocupações das crianças escravas, Maria Cristina Luz Pinheiro, a partir da análise de escrituras de compra e venda de escravos e de inventários post mortem, ambos os documentos decorrentes de Salvador, concluiu que os afazeres domésticos formavam a ocupação mais importante de meninas e meninos escravos (Pinheiro 2005). Sobretudo nas cidades, "as crianças estavam no interior das casas de famílias abastadas, meramente remediadas e, por vezes, nos lares pobres, nos quais eram mão de obra mais acessível, por ser mais barata que a de escravos adultos" (Ariza 2018).

9 Sobre esses aspectos, ver também: Mott (1979) e Mattoso (1988). 
Quando temos em vista o texto de Kátia de Queiroz Mattoso, O filho da escrava, encontramos a seguinte descrição do evoluir da criança cativa no mundo do trabalho: o intervalo na vida da criança que vai dos três aos sete para oito anos é um período de introdução à sociedade dos senhores e também do seu relacionamento com a comunidade escrava.

É nessa idade também, que a criança começará a perceber o que são os castigos corporais, que adentram pela vida adulta [...]. Por volta dos sete para os 8 anos, a criança não terá mais o direito de acompanhar sua mãe brincando; ela deverá prestar serviços regulares para fazer jus às despesas que ocasiona a seu senhor, ou até mesmo, à própria mãe, se esta trabalha de ganho e reside fora da casa de seu dono. [...] A idade de sua vida que vai dos sete aos doze anos, não é mais uma idade de infância, porque já sua força de trabalho é explorada ao máximo [...]. Mesmo se seu rendimento é menor, ele é escravo à part entière, e não mais criança. (Mattoso 1988, 52).

Pesquisando a escravidão na Zona da Mata mineira, ao longo da segunda metade do século XIX, Rômulo Andrade estudou um manual de orientação agrícola escrito pelo padre escravocrata e dono de terras Antônio Caetano da Fonseca, que tinha o intuito de transmitir conhecimentos sobre como gerir as lavouras em um possível contexto de falta de trabalhadores. Nas recomendações do padre, as crianças escravas desempenhariam importante papel a partir dos 5 anos. ${ }^{10}$ Além disso, o trabalho, aliado ao cristianismo, iria moralizar e fortalecer as crianças (Andrade 2001) funcionando, juntamente com os castigos, como engrenagens principais de certa pedagogia senhorial, como apontado por Florentino e Góes (2005).

A relevância e potencialidade da criança escrava, que era considerada em última instância "escravo em redução, somente diferente do escravo adulto que mais tarde será, pelo tamanho e pela força" (Mattoso 1988, 52), também foi percebido por Maria Graham durante a sua viagem pelo Brasil ao longo dos anos 1821-23. A autora relata que:

[Fui ao - GR] asilo de órfãos, que é também ao hospital dos expostos. [...] Dentro de pouco mais de nove anos foram recebidas 10.000 crianças: estas eram dadas a criar fora, e de muitas nunca mais houve notícia. Não talvez porque todas tenham morrido, mas porque a tentação de conservar uma criança mulata como escrava deve, ao que parece, garantir o cuidado com sua vida [...] (Graham 1956, 365).

${ }^{10}$ Sobre os manuais escravistas para a grande lavoura, ver também Marquese (2004). 
Além das atividades desempenhadas pela criança escrava, a importância dos pequenos escravizados também pode ser apreendida, por um lado, por meio da relevante participação desses indivíduos no total das escravarias ${ }^{11}$ e, por outro, por meio do volume de crianças traficadas no comércio atlântico e doméstico de cativos.

Heloísa Maria Teixeira, estudando a localidade de Mariana, percebeu que juntas, as crianças escravas e ingênuas, representavam 29,4\% das escravarias da localidade indicada, entre 1850 e 1888. Separando por segmento social, as crianças escravas correspondiam a $25,6 \%$ do total da população escrava, enquanto os ingênuos eram apenas 3,8\% - já nos anos 1880 , a porcentagem de ingênuos atingiu 16,9\% em relação ao total da população descrita entre os bens dos inventários pesquisados. (Teixeira 2010). ${ }^{12}$

Simonato, pesquisando o parentesco entre os cativos no meio rural do Rio de Janeiro em 1860, encontrou 23,9\% de crianças no total de escravos (Simonato 1998). Por sua vez, Manolo Florentino e Cacilda Machado afirmam que, quando plantéis significativos estão plenamente inseridos no mercado de escravos, as crianças representam recorrentemente cerca de $25 \%$ do total de escravos (Florentino e Machado 1998). ${ }^{13}$

Por sua vez, Herbet Klein aborda criança escrava ao levantar questões relativas ao tráfico internacional de escravos e constata que as crianças correspondiam a cerca de $10 \%$ dos indivíduos traficados e afirma que a despeito de haver oscilações, estes números eram muito constantes (Klein 1987 e 1989). Em pesquisa de 2002, ao estudar a estrutura do comércio transatlântico de escravos no decorrer do século XIX, por meio de amplo volume de dados, além de observar que o tráfico de escravizados continuou privilegiando escravos homens e adultos e notar a ocorrência de significativas variações no volume de homens traficados (provavelmente devido a mudanças nas condições de fornecimento dentro da própria África), Klein lançou luz sobre a considerável ampliação do comércio transatlântico envolvendo crianças e bebês. Fez isso ao chamar atenção para o fato de que enquanto, em média, um quarto dos escravos traficados ao longo do século XVIII eram crianças, a partir do século XIX essa proporção começou a

${ }^{11}$ O que também pode ser verificado pelos censos e outros documentos oficiais como, por exemplo: Brasil. Relatório da comissão geral de estatística da Província de São Paulo, 1888. Ver também Bassanezi (org.) (1999).

${ }^{12}$ Ver também: Teixeira (2002).

${ }^{13}$ Florentino e Machado não definem qual é o tamanho do plantel que permitiu tal observação. Ver também, dentre outros: Slenes (1976). Motta (2012). Luna \& Klein (2010). 
subir e atingiu um máximo de $46 \%$ ao longo da década de 1840 do século XIX.

Gutierres em $O$ tráfico de crianças escravas para o Brasil durante o século XVIII, estudando listas de cativos transportados do porto de Luanda, de 1734 a 1769, também estimou em cerca de $10 \%$ a presença de crianças dentre os cativos comerciados (Gutierres 1989).

A partir da análise de 39 viagens realizadas pelos holandeses da Dutch Middelburgsche Commercie Compagnie, ao longo do século XVIII, David Richardson e Simon Hogerzeil estudaram a relação entre a estratégia de comércio dos traficantes de escravos e a dinâmica de mortalidade dos escravos embarcados. Nesta pesquisa, além de constatarem que as crianças passaram a ter maior atenção dos traficantes em relação aos adultos, observaram que as crianças - que perfizeram quase $20 \%$ dos escravos comprados pelos navios da companhia - suportavam mais tempo embarcadas. Em média, as meninas permaneciam 132 dias e os meninos 124 dias a bordo dos negreiros. Já as mulheres e homens adultos passavam, em média, 101 dias e 91 dias respectivamente. "Em outras palavras, as crianças foram normalmente expostas a condições de bordo por 41 dias a mais do que os adultos. (...) Assim, as estratégias de compra de escravos colocavam as crianças em risco por maiores períodos de tempo do que os adultos" (p. 171). ${ }^{14} \mathrm{O}$ fato de as crianças permanecerem mais tempo embarcadas justifica-se, sobretudo, em virtude das taxas de mortalidade observadas - como indicamos acima a taxa de mortalidade durante as fases de carregamento e travessia dos negreiros foram para os escravizados adultos mais do que o dobro da das crianças. ${ }^{15}$

David Eltis (2008) evidencia que cerca de 12,5 milhões de africanos foram traficados para as Américas entre 1500 e 1867. Desse contingente, cerca de 10 milhões sobreviveram à travessia. Dos 5,5 milhões de escravizados direcionados para à América portuguesa e o Império do Brasil, aproxi-

\footnotetext{
${ }^{14}$ A partir da documentação que pesquisaram, estes autores também consideram as crianças como os indivíduos com até 14 anos. Ver Hogerzeil \& Richardson (2007, 171). Outro elemento que associa a importância da criança escrava e sua participação no comércio transatlântico evidenciado por Eltis e Richardson diz respeito ao fato de esses autores estimarem que um em cada dez navios experimentou algum tipo de rebelião (ocorrida, sobretudo, ainda no litoral africano). As revoltas no século XVIII foram mais recorrentes, principalmente nos navios que viajavam acima do equador. Já durante o século XIX, as crianças envolvidas no tráfico transatlântico foram mais numerosas e assim, a situação a bordo tornou-se mais controlável. Eltis \& Richardson (2010), itálico nosso.

${ }^{15}$ Hogerzeil \& Richardson (2007) também chamam atenção para o fato de que a taxa de mortalidade, ao longo das fases de carregamento dos navios e travessia do Atlântico, entre os homens adultos foi $88 \%$ maior que entre as mulheres adultas.
} 
madamente 4,9 milhões resistiram a travessia atlântica. Quando o autor direciona os seus esforços para a primeira metade do século XIX, afere que dos 2,3 milhões de escravos traficados para o Brasil, ao menos 775 mil foram crianças africanas. Segundo Eltis, as crianças foram ganhando a preferência dos traficantes porque eram mais "maleáveis" que adultos. Tal maleabilidade resultava do fato de as crianças escravizadas: (i) poderem ser treinadas em habilidades específicas; (ii) reagirem melhor à experiência traumática do embarque e travessia atlântica (a taxa de mortalidade das crianças era a metade da observada entre os adultos); (iii) tipicamente não promoverem rebeliões dentro dos navios. ${ }^{16}$

Por seu turno, Valencia Villa e Florentino (2016), a partir do manejo dos registros dos navios negreiros constantes do The Transatlantic Slave Trade Database: Voyages, corroboraram a importância das crianças escravas argumentando que sob as recorrentes restrições estabelecidas pela Inglaterra desde 1810, o trato de gente para o Brasil se adequou até 1850, a um padrão de demanda caracterizado pelas crescentes aquisições de crianças escravizadas, sobretudo meninos cativos. Os autores constatam, por meio de projeções decorrentes da análise de informações oriundas dos negreiros que foram apreendidos e enviados para Serra Leoa e que tinham originalmente como destino as províncias da Bahia, Rio de Janeiro e Pernambuco (regiões que concentravam $72 \%$ de todos os desembarques brasileiros entre 1791 e 1850) - que para o período 1811-1850, houve importante aumento das crianças de ambos os sexos a bordo dos negreiros, em detrimento da participação de homens adultos. As projeções realizadas pelos autores obtiveram os seguintes resultados no que diz respeito à participação das crianças (indivíduos de 0 a 14 anos): 1811-15 (27\%), 1816-25 (37\%), 182635 (48\%), 1836-45 (59\%) e 1846-50 (35\%). Em virtude dos resultados que obtiveram, os autores concluem, dentre outras coisas, "que a plantation podia se ver ante a necessidade de buscar alongar geracionalmente seus efetivos de mão de obra para além do propiciado pela reprodução natural depositada nas africanas que importava" (Villa e Florentino 2016, 3).

A pesquisa de Mary Karasch sobre o Rio de Janeiro, por sua vez, apoia a conclusão de Eltis e Richardson e de Valencia Villa e Florentino acerca do grande volume de crianças traficadas, ao longo da primeira metade do XIX. A autora, além de demonstrar que parte dos registros dos negreiros

${ }^{16}$ Estas informações podem ser encontradas em matéria publicada pela BBC Brasil, em 11 de fevereiro de 2008. Disponível em: https://www.bbc.com/portuguese/reporterbbc/story/2007/04/070405 criancas escravas pu.shtml. Acessado em 14/11/2018. Ver também o banco de dados, Transatlantic Slave Trade Database. Disponível em www.slavevoyages.org. 
vindos da África, após 1830, evidenciaram que quase dois terços dos escravizados tinham menos de catorze ou quinze anos de idade, utilizou relatos de viajantes estrangeiros que visitaram o Rio de Janeiro para corroborar sua constatação. Este é o caso do 'testemunho' do alemão Freireyss, o qual estimou que três quartos dos negros importados, entre 1814-1815, eram crianças (Karash 2000).

Dando um passo à frente, direcionamos nossa atenção para o comércio doméstico de escravos. Quando temos o tráfico interno em vista, podemos perceber a relevância da criança escrava por meio, mais uma vez, da sua significativa participação. José Flávio Motta notou, para a localidade do Oeste paulista de Constituição (chamada posteriormente de Piracicaba), que a negociação de crianças com até 14 anos de idade, entre 1861-1869, representou cerca de $27 \%$ entre os escravos e $36 \%$ entre as escravas. De 1874 a 1880, esta participação reduziu-se para 15,9\% e 19,7\% dos homens e mulheres comerciados (Motta 2012, 146 e 227). Em artigo posterior - agora considerando as crianças escravas como os indivíduos com até 12 anos de idade -, estudando a mesma localidade, Motta evidenciou que no período 1874-1880, as crianças escravas somadas aos ingênuos, estiveram presentes em cerca de um quinto $(19,5 \%)$ do total das vendas ocorridas durante o período de apogeu do tráfico interno de escravos (Motta 2015). Para as cidades de Guaratinguetá e Silveiras (pertencentes ao Vale do Paraíba Paulista), José Flávio Motta e Renato Leite Marcondes notaram que, entre os escravos negociados durante a década de 1870, 28\% corresponderam àqueles com menos de quinze anos de idade (Motta \& Marcondes 2000).

Também podemos apreender a participação das crianças escravas no comércio interno de cativos para as localidades de Areias e Guaratinguetá por meio, mais uma vez, da pesquisa de José Flávio Motta, de 2012. O autor identificou, a partir das escrituras de compra e venda de escravos, que entre 1866 e 1869, "a proporção de crianças na faixa de 0 a 14 anos era superior a um quarto $(26,4 \%)$ " (Motta 2012, 116). Em Guaratinguetá, ao longo do intervalo 1863-1869, "destacou-se a elevada participação relativa, entre os homens, daqueles com idade inferior a 15 anos: 40,3\%. Este percentual igualou-se a $25,2 \%$ no caso das mulheres. Vale dizer, as crianças escravas do sexo masculino foram mais numerosas do que os adultos de 15 a 29 anos (39,5\% dos homens)" (Motta 2012, 129). 
Pesquisando o comércio de escravos em Mariana, entre 1850-1886, Camila Flausino evidenciou que as crianças (até 14 anos) estavam presentes em pouco mais de $27 \%$ das tratativas, sendo $16,1 \%$ meninos e $11,1 \%$ meninas (Flausino 2006). ${ }^{17}$

Ademais, gostaríamos de chamar atenção para dois últimos aspectos que coloca mais uma vez em primeiro plano a relevância das crianças escravas. Por um lado, há as consequências das promulgações de 1869 e 1871. No primeiro ano mencionado, temos o Decreto $n^{\circ} 1.695$, de 15.09.1869. No seu segundo artigo, lemos: "em todas as vendas de escravos, ou sejam particulares ou judiciais, é proibido, sob pena de nulidade, separar o marido da mulher, o filho do pai ou mãe, salvo sendo os filhos maiores de 15 anos" (Brasil 1869, 129-130). Já a Lei do Ventre Livre de 1871 (cuja discussão teve início no parlamento e na imprensa em meados da década de 1860), nos seus parágrafos $7^{\circ}$ e $8^{\circ}$ do artigo $4^{\circ}$, institui que:

Em qualquer caso de alienação ou transmissão de escravos é proibido, sob pena de nulidade, separar os cônjuges, e os filhos menores de 12 anos, do pai ou da mãe. Se a divisão de bens entre herdeiros ou sócios não comportar a reunião de uma família, e nenhum deles preferir conservá-la sob o seu domínio, mediante reposição da quota-parte dos outros interessados, será a mesma família vendida e o seu produto rateado. ${ }^{18}$

Frente a essas leis, acreditamos que possivelmente os senhores omitiam a real situação familiar e a idade dos seus escravos com o fim de manter a sua escravaria e atenuarem a perda de liquidez dos seus cativos. Para tanto, alteravam a idade das crianças escravas, declaravam que elas tinham pais desconhecidos, mortos ou meramente não incluíam esta informação e, por outro lado, afirmavam que os adultos eram na sua maioria solteiros. ${ }^{19}$ Essas simples declarações, na grande maioria dos casos acabavam passando por verdadeiras, permitindo aos senhores desmembrarem famílias escravas e negociarem e manterem escravizadas, após a Lei do Ventre Livre (1871) crianças que de fato eram ingênuas.

${ }_{17}$ Para dados relativos ao município paulista de Campinas, ver Slenes (1976).

${ }^{18}$ Sobre essa e outras discussões acerca dos aspectos legais da escravidão ver, dentre outros: Nequete (1988) e Mattos e Grinberg (2018).

19 Acerca das negociações envolvendo famílias escravas, ver também: Fragoso \& Florentino (1987), Andrade (1988), Motta (1999) e Motta \& Marcondes (2000). 
Nesta linha, Warren Dean indicou que as vendas de escravos registradas em Rio Claro, a partir de 1872, consistiam na maior parte de meninos de 10 a 15 anos, raramente acompanhados dos pais. Esses eram declarados, reiteradamente, como desconhecidos ou mortos (Dean 1977, 69). Rômulo Andrade (1998), também utilizando escrituras de compra e venda de cativos decorrentes da Zona da Mata mineira, sugeriu a prática da mesma estratégia após $1871 .^{20}$

As informações decorrentes da pesquisa que originou este artigo nos permitiram apreender mais um dado que apoia a hipótese mencionada. Constatamos que de todas os escravos e escravas de 16 e 17 anos de idade, negociados entre 1861 e 1871, 36\% desses (a grande maioria com 16 anos) foram transacionados justamente ao longo dos 2 anos e 3 meses compreendidos entre a publicação do decreto de setembro de 1869 - que, como já indicamos, proibia a separação do marido da mulher, o filho do pai ou mãe, salvo sendo os filhos maiores de 15 anos - e a promulgação da Lei do Ventre Livre (1871).

Infelizmente, em virtude da ausência de dados acerca do tráfico interno de escravos preservados pelo primeiro e segundo cartórios de notas e protestos de Rio Claro, para os anos iniciais da década de 1870, não tivemos possibilidade de fazer o exercício presente no parágrafo anterior para os anos subsequentes à promulgação da Lei do Ventre Livre (o que faríamos, nessa oportunidade, com crianças escravas de 13 e 14 anos). Contudo, temos no horizonte a afirmação de Kátia Mattoso $(1988,55)$, a qual enfatiza que, após 1871, a falta de precisão sobre o sexo, o nome, a cor e a idade não se deve ao fato "de que a criança ingênua interessava agora menos aos seus senhores. Na realidade, a falta de dados sobre os ingênuos é talvez mais uma maneira de os senhores aproveitarem-se de situações pouco claras. (...) Os senhores nunca deixaram de bem conhecer o valor dessas crianças".

Por outro lado, os meninos e meninas, sobretudo aqueles com idade mais avançada, desempenhavam importante papel como garantia de crédito. É notório que o ativo mais relevante para o fazendeiro era formado pelos cativos que possuía - eram os escravos, principalmente, que davam dimensão da riqueza do fazendeiro e asseguravam salvaguarda para os empréstimos por ele realizados. Podemos perceber a importância dos escravos como elemento que possibilitava garantia para os créditos adquiridos pelos fazendeiros por meio do livro de José Penido, publicado em 1885 (ano no qual

20 Ver também Motta (2012) e Rossini (2015). 
os escravos deixaram de ser aceitos como garantia de crédito), $A$ abolição e o crédito. Na contracapa do livro de Penido, lemos: "o crédito que se estabelece em base imoral é tão frágil como o edifício que se levanta sobre movediça areia, pois que, aquele falta à confiança, como a este a solidez."

\section{O Tráfico Interno de Crianças Escravas no Oeste paulista. Rio Claro, 1861-1869}

\subsection{Recorte Espacial e Temporal}

Neste artigo, estudamos a dinâmica do comércio interno de crianças escravas a partir de núcleo documental preservado pelos cartórios de notas e protestos de Rio Claro. Essa cidade pertence à área que José Francisco de Camargo chamou de Região da Baixa Paulista (Camargo 1952) ${ }^{21}$ e que se integrou à franja da economia cafeeira de São Paulo, a partir dos anos 1860 e, sobretudo, em decorrência de sua ligação à Campinas, já nos anos 1870, feita pela Cia. Paulista de Estrada de Ferro.

Em virtude dos dados por nós levantados acerca do comércio de escravos ocorrido nesta localidade e, em particular, das negociações envolvendo crianças escravas $(27,2 \%$ de todos os escravos traficados, entre 1861-1869, eram indivíduos com até 14 anos); do percentual de escravos e de crianças escravas residentes (de acordo com o censo de 1872, 26\% da população rio clarense era cativa - ver tabela 1); dos subsídios oferecidos por Camargo (1952), Milliet (1982) e Dean (1977) acerca do número de cafeeiros, do volume de unidades ativas e da quantidade de arrobas produzidas, cremos que Rio Claro configura amostra apropriada para acompanharmos, no período proposto, a dinâmica do tráfico interno de crianças escravas ${ }^{22}$

${ }^{21}$ A composição municipal adotada por J. F. de Camargo - e por extensão a do presente artigo - é a que vigorava até o recenseamento de 1940. Ademais, gostaríamos de pontuar que as regiões do interior de São Paulo, de acordo com Millliet (1982) e Camargo (1952), foram batizadas pelos nomes das estradas de ferro que as cruzavam, em virtude do sincronismo existente entre desenvolvimento econômico, impulso demográfico e expansão da via férrea. Esta definição persiste até os dias atuais no imaginário paulista. Sérgio Milliet, em seu livro Roteiros do café e outros ensaios aponta que os seguintes municípios, no final do século XIX, compunham a Zona Paulista: Rio Claro, Araras, Araraquara, Barretos, Jaboticabal, Descalvado, Limeira, Palmeiras, São Carlos e Santa Rita.

${ }^{22}$ Algumas outras informações sobre o município de Rio Claro encontram-se em: IBGE. Disponível em: http://www.ibge.gov.br/cidadesat/painel/painel.php?codmun=354390\#. Acesso em: 05/09/2018. 
na expansão cafeeira paulista. Vejamos, a seguir, a evolução de dados concernentes à produção cafeeira e ao número de escravos.

Tabela 1

\begin{tabular}{|c|c|c|c|c|c|c|c|c|c|c|}
\hline \multicolumn{11}{|c|}{ População Escrava segundo Grupos de Idade - Rio Claro, Província de São Paulo, 1872} \\
\hline \multirow{2}{*}{ Sexo } & \multicolumn{5}{|c|}{ Anos Completos } & \multicolumn{5}{|c|}{ Faixa etária - Quinquênios } \\
\hline & 1 & 2 & 3 & 4 & 5 & 6-10 & 11-15 & $16-20$ & 21-25 & 26-30 \\
\hline Mulheres & 0 & 0 & 18 & 34 & 63 & 95 & 102 & 118 & 154 & 147 \\
\hline Homens & 0 & 0 & 26 & 39 & 70 & 120 & 154 & 191 & 393 & 227 \\
\hline \% em relação ao total & - & - & 1,12 & 1,86 & 3,38 & 5,46 & 6,51 & 7,85 & 13,90 & 9,50 \\
\hline \multirow{2}{*}{ Sexo } & \multicolumn{7}{|c|}{ Faixa etária - Decênios } & Mais de 100 & Idade não & \\
\hline & $31-40$ & $41-50$ & $51-60$ & $61-70$ & $71-80$ & $81-90$ & $91-100$ & anos & Determinada & Total \\
\hline Mulheres & 299 & 205 & 199 & 84 & 49 & 17 & 19 & 6 & 12 & 1.621 \\
\hline Homens & 360 & 292 & 178 & 125 & 73 & 22 & 15 & 11 & 18 & 2.314 \\
\hline \% em relação ao total & 16,7 & 12,6 & 9,6 & 5,3 & 3,1 & 1,0 & 0,9 & 0,4 & 0,8 & 100,0 \\
\hline
\end{tabular}

Fonte: Os dados utilizados nesta tabela são decorrentes do Censo Geral do Império de 1872, de acordo com a organização de Maria Silvia B. Bassanezi. São Paulo do passado: dados demográficos. Campinas: NEPO/UNICAMP, 1998. 1 CD-ROM.

Por fim, como já indicamos, o artigo se deterá no exame dos dados decorrentes de escrituras manuscritas de compra e venda de escravos, que compulsamos (sempre que disponíveis e legíveis) para o período compreendido entre 1861 e 1869. Nosso recorte temporal se justifica pela maior disponibilidade de escrituras a partir de 1861. Esse maior volume de códices advém do decreto imperial promulgado no final do ano de 1860, que preceituava o lançamento das escrituras de negócios com escravos de valor superior a duzentos mil-réis em livros de notas específicos para essa finalidade. ${ }^{23}$

Concluímos a nossa análise em 1869, em virtude do Decreto nº 1.695, de 15.09.1869 que, como já indicado, proibia a separação de pais e filhos menores de 15 anos de idade. Além disso, levamos em conta as especificidades do início da década de 1870 , resultantes da expectativa, dos debates e do encaminhamento da Lei do Ventre Livre (1871), processo repleto de consequências para a dinâmica da comercialização interna de cativos. ${ }^{24}$

${ }^{23}$ Brasil, Coleção de Leis do Império do Brasil. Disponível em: http://www2.camara.leg.br/atividadelegislativa/legislacao/doimperio. Acesso em: 15/09/2018.

24 A Lei do Ventre Livre estabeleceu que: as crianças nascidas após a efetivação da Lei estariam livres. Porém, a despeito dessa condição, as crianças continuariam a viver com suas mães escravas e sob a autoridade dos senhores de suas mães, "os quais terão a obrigação de criá-los e tratá-los até a idade de oito anos completos. Chegando o filho da escrava a esta idade, o senhor da mãe terá opção, ou de receber do Estado a indenização de $600 \$ 000$, ou de utilizar-se dos serviços do menor até a idade de 21 anos completos. No primeiro caso, o Governo receberá o menor e lhe dará destino, em conformidade da presente lei" (Conrad 1978, 144). Como é notório, a imensa maioria dos proprietários optou pela prestação de serviços. 


\subsection{Aspectos Econômicos e Demográficos acerca do Tráfico Interno de Crianças Escravas}

Ao realizarmos a organização inicial dos dados que obtivemos acerca das crianças cativas e das famílias escravas (estado conjugal e filhos declarados) obtivemos os resultados expostos na tabela e gráficos abaixo.

Tabela 2

\begin{tabular}{|c|c|c|c|c|c|c|c|c|c|c|}
\hline \multirow[b]{2}{*}{ Ano } & \multicolumn{5}{|c|}{ Crianças escravas - sexo masculino } & \multicolumn{5}{|c|}{ Crianças escravas - sexo feminino } \\
\hline & $\begin{array}{l}\text { Número total de } \\
\text { crianças escravas } \\
\text { comercializadas }\end{array}$ & \begin{tabular}{|c|}
$\begin{array}{c}\text { Idade média de todas as } \\
\text { crianças escravas } \\
\text { vendidas } \\
\text { (individualmente e em } \\
\text { grupo) }\end{array}$ \\
\end{tabular} & \begin{tabular}{|c|}
$\begin{array}{c}\text { Crianças } \\
\text { vendidas } \\
\text { individualment } \\
\mathrm{e}\end{array}$ \\
\end{tabular} & $\begin{array}{l}\text { Idade média das } \\
\text { crianças escravas } \\
\text { vendidas } \\
\text { individualmente }\end{array}$ & \begin{tabular}{|c|} 
Preço nominal \\
médio das crianças \\
vendidas \\
individualmente \\
(Contos de Réis) \\
\end{tabular} & $\begin{array}{l}\text { Número total de } \\
\text { crianças escravas } \\
\text { comercializadas }\end{array}$ & \begin{tabular}{|c|} 
Idade média de \\
todas as crianças \\
escravas vendidas \\
(individualmente e \\
em grupo)
\end{tabular} & \begin{tabular}{|c|} 
Crianças \\
vendidas \\
individualmente
\end{tabular} & $\begin{array}{c}\text { Idade média das } \\
\text { crianças escravas } \\
\text { vendidas } \\
\text { individualmente }\end{array}$ & $\begin{array}{c}\text { Preço nominal médio } \\
\text { das crianças vendidas } \\
\text { individualmente } \\
\text { (Contos de Réis) }\end{array}$ \\
\hline 1861 & 14 & 9,0 & 2 & 11,5 & $1: 600 \$ 000$ & 5 & 11,2 & 2 & 11,0 & $1: 575 \$ 000$ \\
\hline 1862 & 3 & 12,6 & 1 & 14,0 & $1: 500 \$ 000$ & 4 & 10,0 & 1 & 14,0 & $1: 600 \$ 000$ \\
\hline 1863 & 14 & 11,8 & 1 & 7,0 & $800 \$ 000 *$ & 9 & 12,2 & 6 & 12,3 & $1: 483 \$ 333$ \\
\hline 1864 & 12 & 11,0 & 5 & 10,6 & $1: 587 \$ 500^{* *}$ & 17 & 10,6 & 5 & 7,8 & $1: 185 \$ 000^{* * *}$ \\
\hline 1865 & 6 & 12,2 & 2 & 12,5 & $1: 600 \$ 000$ & 10 & 10 & 4 & 11,3 & $1: 175 \$ 000$ \\
\hline 1866 & 7 & 13,0 & 3 & 13,0 & $1: 200 \$ 000$ & 5 & $5,4^{* * * * *}$ & 1 & 4,0 & $450 \$ 000$ \\
\hline 1867 & 13 & 12,7 & - & - & - & 2 & 12,0 & 2 & 12,0 & $1: 100 \$ 000$ \\
\hline 1868 & 17 & 9,6 & - & - & - & 2 & 11,0 & 2 & 11,0 & $1: 125 \$ 000$ \\
\hline 1869 & 18 & 12,0 & 4 & 11,3 & $1: 575 \$ 000$ & 1 & 14,0 & 1 & 14,0 & $1: 400 \$ 000$ \\
\hline Total & 104 & 11,5 & 18 & 11,4 & $1: 495 \$ 000$ & 55 & 11,4 & 24 & 10,8 & $1: 232 \$ 593$ \\
\hline $\begin{array}{l}\text { lor baix } \\
\text { âo dis } \\
\text { năo di } \\
\text { ixa ida }\end{array}$ & 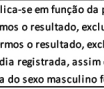 & $\begin{array}{l}\text { (7 anos) da úr } \\
\text { preço médiou } \\
\text { epreço médio, } \\
\text { to preço médio }\end{array}$ & $\begin{array}{l}\text { venda } \\
\text { vicado }\end{array}$ & $\begin{array}{l}\text { criança de ar } \\
\text { ercializaçă } \\
868 .\end{array}$ & $\begin{array}{l}\text { ode idade cor } \\
\text { :ravos com ap }\end{array}$ & ir 200.000. & . & ida & & \\
\hline
\end{tabular}

Com relação à faixa etária das crianças negociadas, fica notória a baixa participação dos pequenos escravos de 0 a 5 anos. Entre 1861 e 1869, houve apenas 14 tratativas envolvendo crianças dessa faixa etária e dessas, somente 3 envolveram a venda de apenas uma criança. Julieta, Geronimo e Bernadina, de respectivamente 1, 3 e 4 anos de idade. Gerônimo e Bernadina foram vendidos por 350 e 450 mil Réis. Julieta, negociada no âmbito do tráfico local, foi comprada por 200 mil reis. Julieta e Gerônimo foram vendidos em 1864 e Bernadina em 1866.

Podemos explicar a pequena participação de escravos da faixa etária mencionada (parte dos quais "crias de peito e de pé"), assim como os seus baixos preços, pela baixa ou não produtividade desses indivíduos, pelo custo envolvido na manutenção desses cativos e em virtude das crianças encontrarem-se sujeitas a altas taxas de mortalidade, sobretudo ao longo do primeiro ano de vida - não por acaso, 93\% das crianças comerciadas sozinhas em Rio Claro, entre 1861-1869, tinham mais de 5 anos. $^{25}$

${ }^{25}$ Maria de Fátima Rodrigues Neves evidenciou que durante o século XIX, a interação entre dieta, doença e trabalho materno constituiu a mais importante causa do elevado número de mortes ob- 
As crianças de 6 a 10 anos de idade representaram 22\% dos indivíduos com menos de quinze anos comercializados em Rio Claro, ao longo do período que temos em vista. Ao restringirmos as nossas observações aos pequenos escravos negociados individualmente, percebemos significativa elevação do preço nominal médio tanto dos meninos como das meninas em relação à faixa etária anterior. Essa elevação pode ser explicada pela drástica queda na taxa de mortalidade e pelo fato, evidenciado por parte da literatura conexa, de que a partir dos 7 anos a criança mudava de status, pois já era possível exigir do pequeno escravo(a) maior interação com atividades do mundo do trabalho, as quais, inclusive, compunham a sua formação. Atividades essas que eram intensificadas até os 14 anos, quando se admitia que o jovem tornava-se um trabalhador completo.

A faixa etária de 12-14 anos abarcou a maior parte das crianças negociadas individualmente ( $61 \%$ dos meninos e $58 \%$ das meninas), cujos preços nominais médios dos meninos e meninas (vendidos sozinhos) atingiram, respectivamente, 1:595\$455 e 1:535\$000, enquanto, a título de comparação, os preços médios nominais dos escravos adultos jovens (15-29 anos) vendidos individualmente, na mesma localidade e ao longo do mesmo período, foram de $1: 775 \$ 979$ e $1: 552 \$ 200 .{ }^{26}$ Importa termos em vista que os preços elevados alcançados pelos meninos e meninas de 12 a 14 anos de idade (ver gráfico abaixo), assim como a considerável demanda por crianças escravas de 6 a 14 anos, evidenciam também as expectativas dos escravocratas sobre a longevidade da escravidão ao longo da década de 1860 .

servadas na população infantil cativa. "Já a mortalidade pós-neonatal (do $1^{\circ}$ ao $12^{\circ}$ mês de vida) e das crianças maiores vinculava-se estreitamente às condições de alimentação nos primeiros meses e anos de vida" (Neves 1994, 59). Ainda com relação às crianças de 0 a 5 anos, Warren Dean em sua pesquisa sobre Rio Claro, apurou que a proporção de crianças sobreviventes em relação às mulheres em idade fértil era mais do que três vezes maior para as mulheres livres do que para as escravas (Dean 1977). Ver também: Ariza (2018) e Machado (2018).

26 Preços decorrentes da venda de: (i) 48 escravos homens, com idade média de 20 anos; (ii) 35 mulheres, com idade média de 19,4 anos. Infelizmente não foi possível discutir a plausível maior importância e preço das escravas que foram vendidas juntamente com seu(s) filho(a)(s) escravo(a) (s), pois não localizamos nenhum registro envolvendo apenas venda de criança(s) cativa(s) com a respectiva mãe. Importa termos em vista a significativa menor distância dos preços dos escravos que acabamos de indicar com os escravos outrora traficados no bojo do tráfico internacional e desembarcados nas Américas Ibéricas, grosso modo até meados do século XVIII. Para estes últimos eram atribuídas frações do preço de um escravo adulto do sexo masculino e de alta qualidade, o qual era denominado pieza de Índia. Ao longo do período indicado, uma criança, habitualmente, tinha um preço correspondente a meia pieza. Cf. Eltis, 2010. 


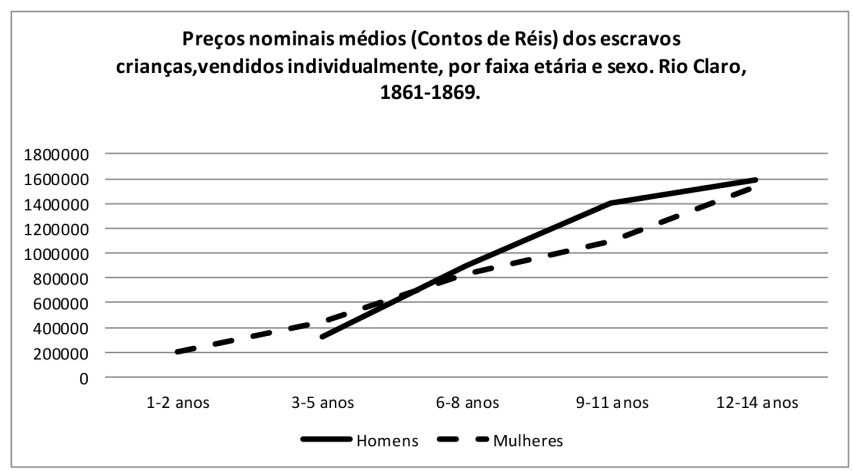

\section{Gráfico 1}

Fonte: Escrituras de compra e venda de escravos preservadas pelos cartórios de notas $\left(1^{\circ}\right.$ e $\left.2^{\circ}\right)$ de Rio Claro. Coleta e compilação de dados próprias.

Ademais, além de não verificarmos diferença importante de preços entre os meninos e meninas púberes, apreendemos, por meio dos dados expostos nos gráficos abaixo, que enquanto o preço nominal médio das crianças cativas do sexo masculino, da última faixa etária mencionada, ficou um pouco aquém do preço dos homens cativos com idade entre 30 e 40 anos $(1: 673 \$ 000),{ }^{27}$ o preço médio das escravas de 12 a 14 anos foi significativamente maior do que o das cativas entre 30 e 40 anos de idade - isso é verdade, quando desconsideramos nos gráficos a seguir a maior variação de preços dos escravos e escravas ocorrida quando eles atingiram cerca de 26 - 27 anos, o que se justifica pelo baixo número de vendas individuais de cativos com essas idades. Acreditamos que essa última constatação resulta da maior expectativa de vida e de trabalho do primeiro grupo, além da maior possibilidade reprodutiva das escravas. ${ }^{28}$

${ }^{27}$ Ao longo do presente texto, quando abordamos o preço nominal médio dos escravos, sempre temos em vista cativos vendidos individualmente. Este cuidado é relevante, pois a forma prosaica de registro das escrituras de compra e venda de escravos ocasionam algumas dificuldades. A mais recorrente foi originada pelas escrituras de compra-venda de mais de um escravo. Essas normalmente não especificavam o preço de cada indivíduo, mas sim o preço do conjunto dos escravos negociados, o que impossibilitou atribuirmos, de forma apropriada, o preço dos escravos de acordo com sua respectiva idade, sexo, habilidade etc.

28 Além disso, vale pontuarmos uma informação, decorrente do Gráfico 1, que nos chamou atenção: meninos com idades entre os 9 e os 11 anos eram mais valorizados que meninas da mesma faixa etária. Tal informação ganha relevância quando temos em vista que outros estudos apontam que a maturação mais rápida das jovens escravizadas tornava o seus preços maiores do que os das crianças escravas do sexo masculino da mesma faixa etária. Esta circunstância talvez decorra do fato de que a despeito dos meninos e meninas serem levados muito cedo ao trabalho, as meninas provavelmente eram direcionadas, mais recorrentemente, para atividades que exigiam mais tempo na casa dos senhores, enquanto os meninos eram conduzidos para a lavoura (Pinheiro 2005). 

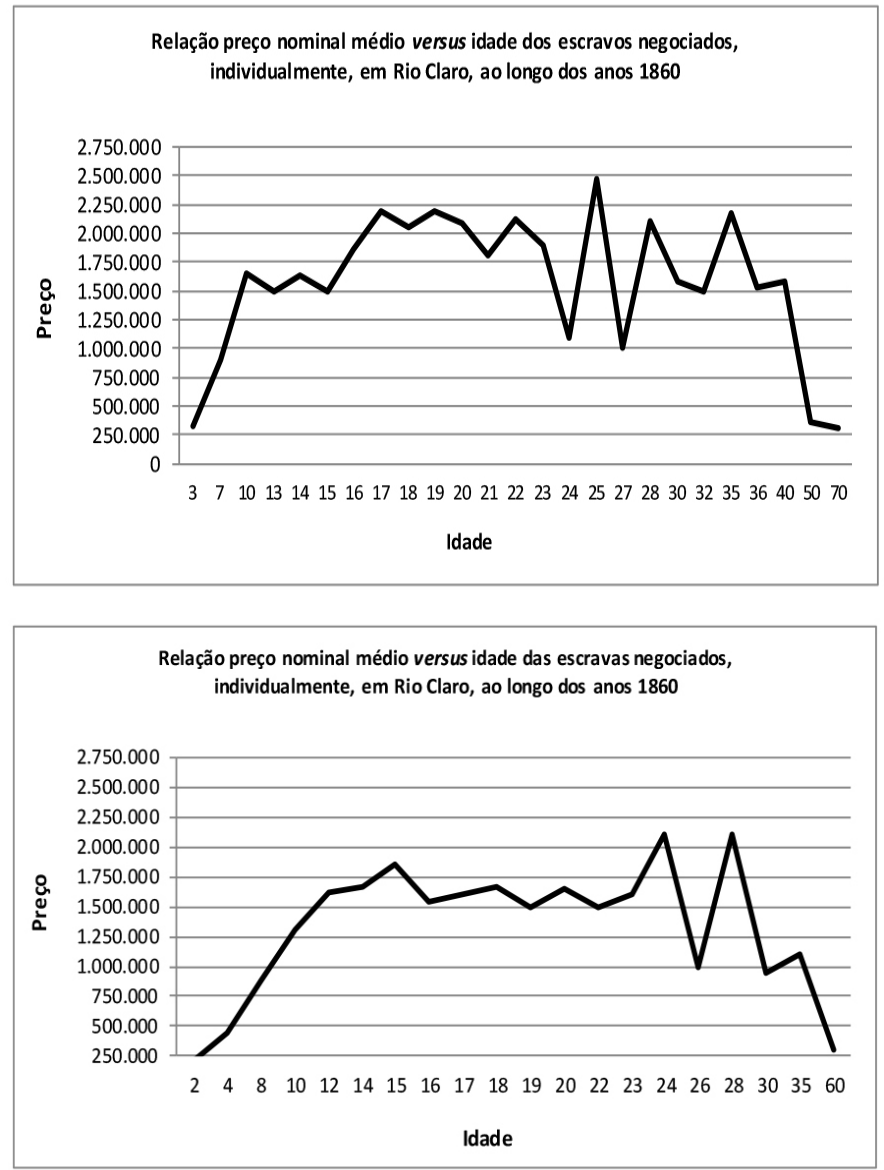

Gráficos 2 e 3

Obs. O Eixo horizontal (idade) aparece de forma distinta nos gráficos, pois são utilizadas somente as idades dos escravos(as)efetivamente comercializados

Fonte: Escrituras de compra e venda de escravos preservadas pelos Cartórios de Notas $\left(1^{\circ}\right.$ e $\left.2^{\circ}\right)$ de Rio Claro. Coleta e compilaçã de dados próprias.

Os dados evidenciados pelo próximo gráfico (elevado número de escrituras de compra e venda que não trouxeram informações sobre o estado conjugal e indicações acerca da existência de filhos dos escravos transacionados) indicam a maior fragilidade da famílias escravas após o fim do tráfico transatlântico de cativos. Contudo, a despeito de as transações de compra e venda de cativos favorecerem a instabilidade da família escrava, não compartilhamos das formulações que afirmam que os escravos foram 
incapazes de formar famílias estáveis, de aculturação e de exercer participação política. ${ }^{29}$

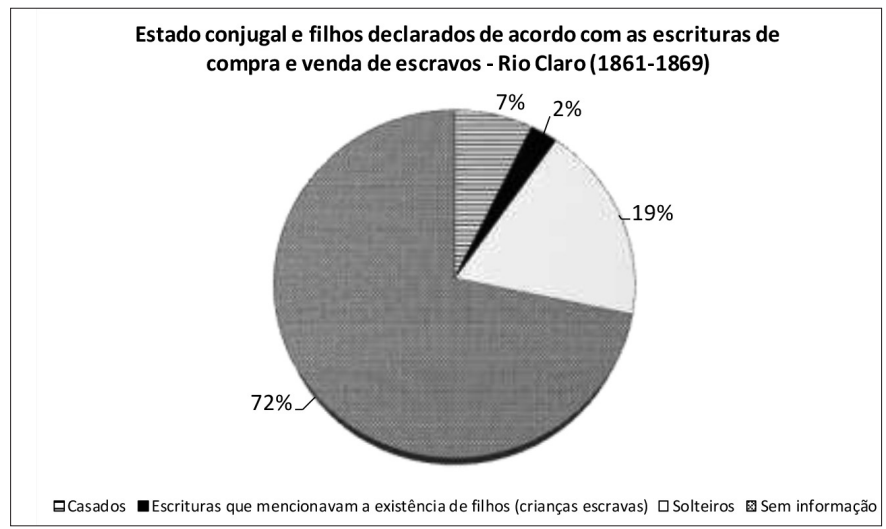

\section{Gráfico 4}

Fonte: Escrituras de compra e venda de escravos preservadas pelos Cartórios de Notas $\left(1^{\circ}\right.$ e $\left.2^{\circ}\right)$ de Rio Claro. Coleta e compilaçã de dados próprias.

Chamamos atenção para o fato de que alguns estudos demográficos, realizados sobretudo ao longo dos anos 1990 e 2000, ${ }^{30}$ ajudam-nos a qualificar o quadro empírico referente à família escrava e por extensão à criança escravizada. Essas investigações apresentam, como resultado comum, além da larga preponderância de escravos homens, taxas de casamento formal, isto é, feito na igreja, em fazendas com 10 ou mais escravos que giravam

${ }^{29}$ Vale notar que, em Ser escravo no Brasil, Kátia Mattoso hesitou acerca da ideia de que um grupo subalterno - mesmo que escravizado - pudesse ser totalmente "domesticado", psicológica e culturalmente, por seus dominadores (Mattoso 2003). Diversos outros autores questionaram a noção de que, pela brutalidade do regime, o escravo era desguarnecido de qualquer ação autônoma, cabendo aos abolicionistas, tidos como pessoas ilustradas e progressistas, o papel de conscientizá-lo, politizá-lo e de resgatá-lo da sua situação. Ou seja, que prevalecia dentre os escravos condição de anomia, tal como postulado, dentre outros, por Florestan Fernandes em A Integração do Negro na Sociedade de Classes. Slenes evidencia que a despeito da violência intrínseca ao sistema, os escravos possuíam forte sentimento da importância dos laços familiares e em diferentes situações agiam de forma autônoma. Os escravos não tiveram o mesmo sucesso que os imigrantes no pós-abolição em função dos mecanismos de exclusão da "sociedade de classes" (Cf. Slenes 2011). Ademais, quando nos deparamos com os crimes cometidos por escravos (homicídios contra senhores, feitores, capatazes, furto da produção agrícola, sabotagens etc.) notamos que essas ações eram produtos da vida cotidiana nas fazendas e atribuíam ao cativo papel relevante como agente social e sujeito histórico. Ver também: Machado (2014), Azevedo (1987), Lara (1988), Pirola (2011), Slenes (2010). Sobre a família escrava, ver, dentre outro: Fragoso \& Florentino (1972, Slenes (1976) e Motta (1999).

${ }^{30}$ Ver, por exemplo, Teixeira (2002), Motta (1999), Rios (2003), Góes (1998) e Klein (1987, 1989 e 2018). 
entre $2 / 5$ e 1/3 das escravarias. Indicam também, para essas propriedades, larga estabilidade das famílias conjugais formadas (entre cônjuges e na convivência entre pais e filhos). No que diz respeito à duração das uniões entre mães e filhos escravos, a pesquisa de Teixeira (2002) sobre Mariana evidenciou - por meio da observação da idade dos filhos mais velhos presentes nos inventários post-mortem - que essa duração crescia expressivamente conforme aumentava a idade das mães. Por exemplo, quando as mães tinham mais de 40 anos, essas conviveram com seus filhos mais velhos por mais de 20 anos e as mães com mais de 50 anos viveram com o filho mais velho por mais de 30 anos. Ademais, encontramos em Teixeira, assim como em outras pesquisas acerca da família escrava, formulações que afirmam que a partilha das propriedades senhoriais entre herdeiros normalmente não separavam casais e pais e filhos. ${ }^{31}$ Deste modo, tal como afirma Robert Slenes, nas médias e grandes propriedades com anos de operação, a estabilidade familiar foi recorrente e se exprimia na existência de famílias extensas, contando com a presença de três gerações e a convivência entre irmãos adultos e seus respectivos filhos (Slenes 1998 e 2010). ${ }^{32}$ Assim, se o tráfico transatlântico e interno direcionava novos contingentes de cativos (principalmente homens) para as fazendas do sudeste, não é verdade que a maioria dos escravos - muito menos a maioria das mulheres e das crianças - estivessem perdidos uns para os outros. ${ }^{33}$

${ }^{31}$ Heloísa Maria Teixeira (2002), verificou que, "para os inventários nos quais as partilhas foram realizadas, mais da metade $(63,9 \%)$ das famílias escravas passou incólume pelo momento da partilha no período de 1850 a 1888." Ademais, a autora notou que as famílias que não permaneceram totalmente unidas após o momento da partilha, na maioria das vezes apenas um membro da família foi separado. Ver também Rocha (2004).

${ }^{32}$ Situação que seria acentuada em estabelecimentos apartados do mercado de compra e venda de cativos por longos períodos. Em fazendas que por 20 anos não compravam cativos, além do equilíbrio entre os sexos ser a norma, as crianças podiam corresponder a um terço da escravaria. Em propriedades afastadas do mercado há mais de 50 anos, as crianças correspondiam a quase metade de todos os cativos. Por exemplo, o plantel de escravos da fazenda Chuao, estudado por Florentino e Machado, estava há longo tempo desvinculado do mercado, entre 50 e 70 anos. Como resultado dessa situação, o plantel em questão era formado majoritariamente por mulheres ( $44 \%$ é a taxa de masculinidade) e possuía, em 1808, grande número de crianças (46\%) (Florentino e Machado 2000).

33 Slenes afirma que a família escrava emerge de um processo de conflito entre escravo e senhor. "O senhor é forçado a ceder certo espaço para os escravos formarem famílias, encarando isso, porém, como parte de uma política de desmonte de revoltas. A política funciona até certo ponto, pois, ao dar ao escravo algo a perder, ela o torna mais vulnerável, transforma o cativo em refém" (Slenes 2000, 3). No decorrer do tempo, todavia, esse espaço acaba sendo amplamente subversivo, pois é usado pelos escravos como lugar de concepção e comunicação de uma identidade própria, adversa à dos senhores e tecida a partir da descoberta de certas tradições africanas compartilhadas. Disponível em: http://wwwl.folha.uol.com.br/fol/brasil500/ entre_14.htm. Acesso em: 04/02/2015. Por sua vez, Florentino e Góes (1997) propõe que o parentesco e a família escrava constituía o cimento da comunidade cativa e possibilitava dirimir conflitos e permitia a paz das senzalas. Ainda, cabe não perdermos do horizonte que, tal como propõe José Flávio Motta e Renato Leite Marcondes (2000, 293), se afastarmo-nos do âmbito da família nuclear ou matrifocal, e "pensarmos no elenco dos tios, avós, sogros, cunhados etc., e mesmo indo mais além, nas relações de compadrio", podemos aventar 
Os dados relativos às crianças escravas vendidas com ou sem os pais, sozinhas ou em grupo, nos ajudam a apoiar a formulação anterior. Apesar das escrituras que registraram a venda de crianças escravas normalmente não trazerem referência aos pais (apenas 9\% dos códices compulsados indicaram que as crianças foram vendidas acompanhadas dos pais), 91\% dos indivíduos com idade igual ou menor a 14 anos foram comerciados no interior de grupos de cativos. O grande número de escrituras que não fizeram qualquer referência aos pais das crianças negociadas pode ser justificado (como já mencionamos) pela omissão, por parte dos senhores, da real situação familiar dos escravos transacionados, pela elevada taxa de mortalidade escrava e também pela dinâmica das fugas e alforrias. ${ }^{34}$

Com relação à tipologia do comércio doméstico de crianças cativas, o tráfico local (transações realizadas entre diferentes proprietários residentes em Rio Claro) foi preponderante entre as crianças vendidas individualmente (43\%), ${ }^{35}$ já entre os escravos vendidos em grupo, as transações intraprovinciais (isto é, majoritariamente entre a localidade que temos em apreço e algum outro município da Província de São Paulo) foram maioria (33\%). ${ }^{36}$ Com relação às crianças traficadas em grupo, organizamos as informações que obtivemos nos gráficos abaixo.

Além desses aspectos, no que diz respeito ao tráfico intraprovincial e interprovincial as entradas em Rio Claro, prevaleceram largamente às saídas desta localidade - as escrituras de compra e venda registraram a entrada de $65 \%$ por meio do comércio intraprovincial e $86 \%$ no âmbito do comércio interprovincial.

que para diversos cativos o fado da venda não significou a plena ruína da vida familiar. Outrossim, o próprio batismo representou muito mais a formação de um parentesco entre escravizados do que a inserção dos mesmos na comunidade cristã (Goés e Florentino 1999).

${ }^{34}$ Góes e Florentino (1999), pesquisando inventários fluminenses, apontaram que as crianças escravas que escapavam da morte prematura, iam, aparentemente, perdendo os pais antes mesmo de completarem um ano de idade. Os autores assinalam que uma entre cada dez crianças já não possuía nem pai nem mãe anotados nos inventários. Aos 5 anos metade parecia ser órfã; aos 11 anos, 8 em cada 10. Ademais, as alforrias também faziam desaparecer dos registros os pais. Sobre algumas das formas de resistência escrava como as fugas, os suicídios etc., ver Santos (1980). Segundo Ariza (2018, 171), "notadamente até a década de 1850, as taxas de mortalidade da população cativa inviabilizavam o seu crescimento, e a continuidade da escravidão devia-se sobretudo à reposição de braços proporcionada pelo tráfico." Importa termos em vista que a dinâmica da mortalidade escrava não muda substancialmente após a abolição do comércio atlântico de escravizados.

${ }^{35}$ Entre as crianças vendidas individualmente o comércio intraprovincial e interprovincial registraram, respectivamente, $9 \%$ e $12 \%$. Nenhuma informação foi lançada para as demais transações (36\%).

${ }^{36}$ Para além do tráfico intraprovincial, dentre as crianças escravas vendidos em grupo, temos as seguintes informações: 19\% das transações ocorreram por meio do comércio local, 17\% por meio do intraprovincial e $31 \%$ das vendas foram registradas sem informações que nos permitissem identificar a tipologia do tráfico interno. 


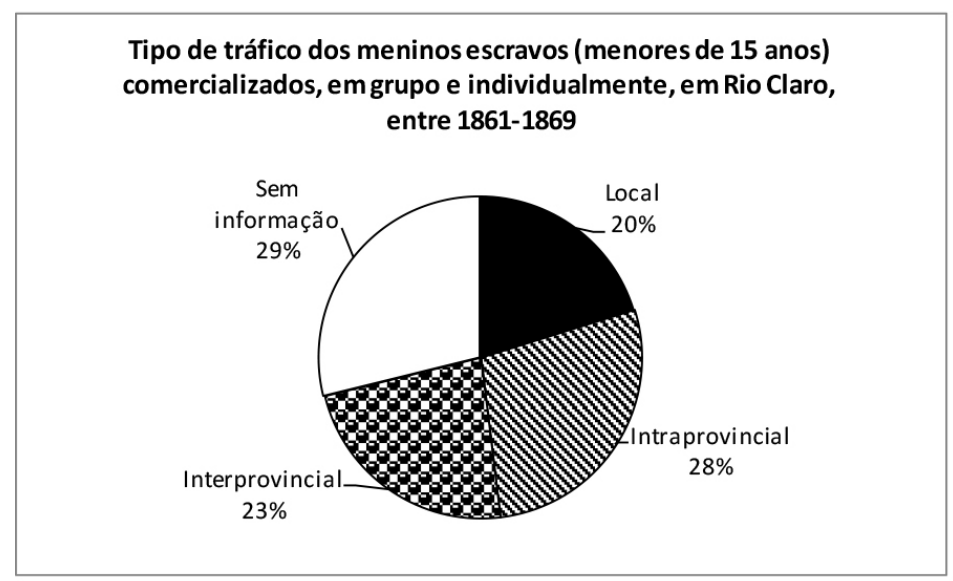

Tipo de tráfico das meninas escravas (menores de 15 anos) comercializadas, em grupo e individualmente, em Rio Claro, entre 1861-1869

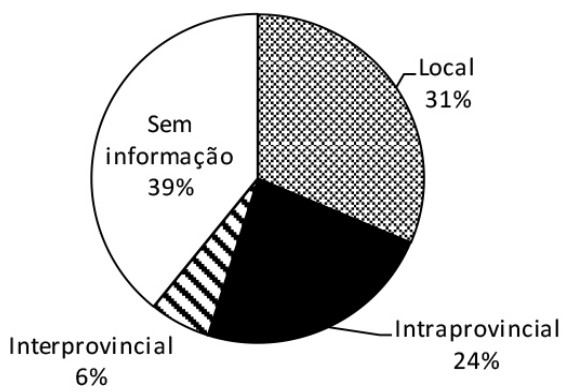

Gráficos 5 e 6

Fonte: Escrituras de compra e venda de escravos preservadas pelos Cartórios de Notas $\left(1^{\circ}\right.$ e $\left.2^{\circ}\right)$ de Rio Claro. Coleta e compilaçã de dados próprias.

Ademais, fazemos alguns apontamentos acerca de outro aspecto de grande acuidade, qual seja: a relação ocupação/experiência-preço. Das crianças escravas envolvidas nas diversas transações que organizam as apreciações aqui empreendidas, obtivemos o informe da ocupação de apenas 18 indivíduos, majoritariamente cativos do sexo masculino possuindo entre $12 \mathrm{e}$ 14 anos de idade. 
Dentre os escravizados elencados na tabela a seguir, alguns foram vendidos individualmente. Temos o caso da Maria, escrava de 14 anos, preta e dedicada ao serviço doméstico. Ela foi vendida, no âmbito do comércio local, em agosto de 1868, por Francisco A. Negreiros, integrante de tradicional família escravocrata da região, a José Martinho A. Pacheco, por um 1:500\$000 Réis. Outro caso ilustrativo diz respeito à venda de Silvestre, pardo, de apenas 7 anos, dedicado ao artesanato, também vendido localmente. Para ter acesso a essa criança, o Padre Manoel R. C. Pinto pagou a quantia de um conto de Réis a José J. Alves, em uma transação ocorrida em meados de 1869.

Tabela 3

\begin{tabular}{l|c|c|c|c}
$\begin{array}{c}\text { Ocupação e preços médios nominais das crianças } \\
\text { es cravas negociadas em Rio Claro (1861-1869) }\end{array}$ \\
\hline \multirow{2}{*}{ O cupação } & \multicolumn{2}{c}{ Homens } & \multicolumn{2}{c}{ Mulheres } \\
\cline { 2 - 5 } & $\begin{array}{c}\text { N. de } \\
\text { escravos }\end{array}$ & $\begin{array}{c}\text { Preço } \\
\text { médio } \\
\text { (Réis) }\end{array}$ & $\begin{array}{c}\text { N. de } \\
\text { escravos }\end{array}$ & $\begin{array}{c}\text { Preço } \\
\text { mé dio } \\
\text { (Ré is) }\end{array}$ \\
\hline Lavoura & $12 *$ & $1: 728 \$ 571$ & - & - \\
\hline Serviço doméstico & - & - & $4 * *$ & $1: 643 \$ 750$ \\
\hline Servente & 1 & $1: 650 \$ 000$ & - & - \\
\hline Artesanal & 1 & $1: 000 \$ 000$ & - & - \\
\hline
\end{tabular}

*Todos meninos de 12 a 14 anos de idade. ${ }^{* *}$ todas meninas de 12 a 14 anos de idade.

Fonte: Escrituras de compra e venda de escravos preservadas pelos Cartórios de Notas $\left(1^{\circ}\right.$ e $\left.2^{\circ}\right)$ de Rio Claro. Coleta e compilaçã de dados próprias.

Por fim, quando temos em vista a totalidade das crianças negociadas, observamos que a razão de sexo decorrente do tráfico interno dos indivíduos com até 14 anos de idade, ao longo dos recortes espacial e temporal que temos em vista, foi de 204 escravos para cada 100 escravas negociadas. O que evidencia larga preponderância do sexo masculino, aspecto observado recorrentemente no âmbito do comércio doméstico de escravos. ${ }^{37}$

\footnotetext{
37 Também buscávamos neste artigo fazer certo confronto de parte dos dados que compulsamos com informações decorrentes da primeira metade da década de 1870, período repleto de especificidades em virtude das expectativas, efetivação e consequências da lei do Ventre Livre (1871) - sobretudo, entre 1870-73. Em virtude desta lei, o tráfico interno de escravos, durante a primeira metade da década de 1870, conviveu com muitas incertezas o que fez com que a expansão do comércio doméstico de cativos verificada na década de 1870 ocorresse, sobretudo, a partir de 1874. (Ver Motta 2012). Contudo, não foi possível apreendermos o impacto da Lei de 1871 sobre o comércio de crianças, pois ao pesquisarmos os dados de Rio Claro acerca do aludido tráfico, para os anos 1870, verificamos a existência de lacuna significativa. Não havia dados preservados pelos cartórios de Rio Claro para o intervalo 1871 - 1875. Este importante vazio justifica-se, provavelmente, pelo extravio de dois dos cinco livros, destinados ao registro do comércio interno de cativos, que eram preservados pelo $2^{\circ}$ Cartório de Notas e Protestos de Rio Claro.
} 


\section{Considerações Finais}

Ao nos debruçarmos sobre parte da bibliografia acerca da criança escrava e ao organizarmos as informações atinentes ao comércio interno desses indivíduos decorrentes da localidade de Rio Claro, percebemos a importância desse grupo. Fato que distancia as nossas conclusões das inferências de parte da literatura relativa ao tema que afirma que as crianças cativas eram "um peso quase morto (...), pois o seu senhor tinha de sustentá-la até que fosse útil como máquina de trabalho. Além de dificultar o trabalho da mãe, somente após os dez anos, mais ou menos, começava a trabalhar" (Moura 2004, 118).

Em virtude da pesquisa realizada, acreditamos que a formulação anterior adeque-se as chamadas "crias de peito" e "crias de pé", isto é, crianças de 0 a 5 anos de idade. Contudo, a despeito da possível relevância desse grupo em fazendas que possuíam escravarias numerosas, essas crianças constituem recorrente minoria no âmbito do tráfico interno de escravos em Rio Claro, por exemplo, 93\% das crianças negociadas sozinhas, entre 1861-1869, tinham mais de 5 anos. Contrariando a perspectiva que reproduzimos no parágrafo anterior, atribuímos importância à criança escrava (principalmente aquelas com mais de 5 anos), o que se justifica pela(s): (i) considerável participação das crianças cativas no total das escravarias mencionadas neste artigo; (ii) quantidade de crianças traficadas no comércio atlântico e doméstico de escravos; (iii) possibilidade das crianças suportarem mais tempo embarcadas nos navios negreiros; (iv) perspectiva de uma vida mais longa (o que também evidência as expectativas dos escravocratas, ao longo da década de 1860, sobre a longevidade da escravidão); (v) possibilidade de serem adquiridas por preços mais baixos, sobretudo as crianças com menos de 12 anos de idade; (vi) tarefas exercidas precipuamente por crianças; (vii) maior facilidade com que se adaptavam ao trabalho; (viii) provável movimentação dos senhores para manter a liquidez das suas crianças escravas tendo em vista o Decreto de 1869 e a Lei de 1871; (ix) sua participação como garantia de créditos contratados pelos seus senhores.

Parte dos aspectos que acabamos de mencionar, podem ser corroborados por meio dos dados que mobilizamos para este artigo, decorrentes, sobretudo, de escrituras manuscritas de compra e venda de escravos preservadas pelo $1^{\circ}$ e $2^{\circ}$ cartórios de notas e protestos da localidade estudada. Esses 
possibilitaram a análise de aspectos econômicos, demográficos e relativos ao trabalho das crianças que sofreram a sina do tráfico interno de seres humanos, entre 1861 e 1869.

A partir dos documentos compulsados percebemos - como aparece recorrentemente na bibliografia relativa ao tráfico interno de escravos - que no âmbito do comércio doméstico de crianças ficou notória a prevalência das negociações envolvendo meninos (tanto nas vendas individuais quanto no interior de grupos). Além disso, como já indicado, houve baixa participação dos pequenos escravos de 0 a 5 anos. A exígua participação deste grupo pode ser explicada pela baixa produtividade desses indivíduos, pelos gastos que o senhor teria que incorrer para mantê-los e em virtude de as crianças dessa faixa etária estarem sujeitas a elevadas taxas de mortalidade.

Os escravos de 6 a 10 anos corresponderam a quase 1/4 das crianças negociadas. A partir da observação dos cativos desta faixa etária, transacionados sozinhos, percebemos significativa elevação do preço nominal médio dos meninos e meninas. Os maiores preços verificados podem ser elucidados em virtude da menor mortalidade e resultado de maior proximidade dos escravos com atividades rotineiras de trabalho a partir dos 7 anos de idade. Afazeres que eram acentuados até os 14 anos, quando o escravo passava a ser considerado um trabalhador pleno. A maioria das crianças escravas transacionadas possuía de $12-14$ anos (61\% e 58\%, respectivamente, dos meninos e meninas negociados).

Em relação às famílias escravas, ficou manifesta a reiterada ausência de informações sobre o estado conjugal e presença de filhos acompanhando os escravos adultos vendidos. Apenas 19\% das escrituras pesquisadas indicaram que os cativos vendidos eram solteiros, $7 \%$ que eram casados e tão só $2 \%$ dos documentos indicaram que a criança escrava havia sido negociada juntamente com um dos pais (normalmente a mãe).

Esses resultados contrastam com as pesquisas organizadas a partir de outras fontes que não as escrituras de compra e venda de escravizados - inventários post-mortem - que, por um lado, evidenciam a existência de importantes contingentes de escravos casados, inclusive com o aval da igreja Católica, sobretudo em propriedades com 10 ou mais escravos. Talvez parte dos resultados que obtivemos e o evidente contraste indicado resultem, em parte, das discussões, expectativas e da efetiva promulgação do Decreto de fins de 1869 e da Lei do Ventre Livre de 1871, que procuraram 
coibir a fragmentação da família escrava no momento da venda dos cativos. Assim, acreditamos que para evitar a possível perda de liquidez dos seus escravizados, os proprietários omitiam relevantes informações concernentes a eles no momento do registro da venda.

Quando temos em vista a tipologia do tráfico interno de crianças escravas, verificamos que o comércio local foi preponderante entre aquelas comerciadas individualmente. Por sua vez, as transações intraprovinciais foram as mais significativas entre os cativos vendidos em grupo.

Finalmente, a partir da relação ocupação/experiência-preço das crianças envolvidas nas diversas transações apreendidas pela nossa pesquisa, percebemos que a maioria das crianças vendidas, cuja experiência foi mencionada na escritura que registrou a transação, era do sexo masculino e tinha entre 12 e 14 anos de idade, e que as atividades relacionadas à lavoura foram as mais recorrentes entre os escravos e as meninas ocupavam-se sobretudo dos serviços domésticos.

\section{Referências}

Fontes primárias manuscritas

Livros de notas gerais e aqueles destinados ao registro da compra e venda de escravos preservados pelo Primeiro Cartório de Notas e Protestos de Rio Claro (1861-1869).

Fontes secundárias

Alencastro, Luiz Felipe In Schwarcz, Lilia Moritz e Gomes, Flávio dos Santos (Orgs.). 2018. Dicionário da escravidão e liberdade. São Paulo: Companhia das Letras.

Andrade, Rômulo. 1998. Havia um mercado de famílias escravas? (A propósito de uma hipótese recente na historiografia da escravidão), Locus: Revista de História 4(1).

Andrade Rômulo. 2001. Legitimidade e alforria de crianças escravas na província de Minas Gerais. X Congresso Internacional da Aaladaa. Rio de Janeiro. Anais.

Azevedo, Elciene. 1999. Orfeu de Carapinha, Campinas, SP. Ed. UNICAMP.

Azevedo, Elciene. 2010. O direito dos escravos. Campinas, SP: Editora Unicamp.

Azevedo, Célia M. M. 1987. Onda negra, medo branco: o negro no imaginário das elites, século XIX. Rio de Janeiro: Paz e Terra.

Bassanezi, Maria Sílvia C. Beozzo (org.). 1999. São Paulo do passado: dados demográficos, 1836-1920. Núcleo de Estudos de População - NEPO, Universidade Estadual de Campinas - UNICAMP.

Bethell, Leslie. 2002. A abolição do tráfico de escravos no Brasil: A Grã-Bretanha, o Brasil e a questão do comércio de escravos 1807-1869. Brasília: Senado Federal, Conselho Editorial. 
BRASIL, Coleção de Leis do Império do Brasil. Disponível em: http://www2.camara.leg.br/atividade-legislativa/ legislacao/doimperio.

Camargo J. F. de. 1952. Crescimento Populacional no Estado de São Paulo e seus Aspectos Econômicos. Ensaio Sobre a Relação Entre Demografia e Economia. Boletim N. 153 Economia Política e História das Doutrinas Econômicas. São Paulo: USP.

Cano, Wilson. 1983. Raízes da concentração industrial em São Paulo. 2. ed. São Paulo: T. A. Queiroz.

Cano, Wilson. 1985. Padrões diferenciados das principais regiões cafeeiras (1850-1930). Revista de Estudos Econômicos 15(2): 291-306, mai-ago, São Paulo.

Chalhoub, Sidney. 2012. A Força da Escravidão: Ilegalidade e Costumes no Brasil Oitocentista. São Paulo: Companhia das Letras.

Conrad, Robert. 1978. Os últimos anos da escravidão no Brasil: 1850-1888. Rio de Janeiro: Civilização Brasileira.

Costa, Emília Viotti da. 1997. Da senzala à colônia. São Paulo: Ed. Unesp.

Costa, Wilma Peres. 2002. A economia mercantil escravista nacional e o processo de construção do Estado no Brasil. In. História econômica da independência e do Império. Szmrecsanyi, Tamás e Lapa, J. R. Amaral (Orgs.) São Paulo: EDUSP, Imprensa Oficial e HICITEC.

Dean, Warren. 1977. Rio Claro: um sistema brasileiro de grande lavoura, 1820-1920. Rio de Janeiro: Paz e Terra.

Eltis David, Behrendt Stephen D. e Richardson, David. 2000. A participação dos países da Europa e das américas no tráfico transatlântico de escravos: novas evidências. Afro-Ásia 24: 9-50.

Eltis, David e Richardson, David (orgs.). 2008. Extending the Frontiers: Essays on the New Transatlantic Slave Trade Database, New Haven e Londres: Yale University Press.

Eltis, David, Behrendt, Stephen, Richardson, David e Herbert Klein. 1999. The Transatlantic Slave Trade, 15271867: A Database on CD-ROM, New York: Cambridge University Press.

Eltis, David. In. Construção do Banco de Dados do Tráfico de Escravos Transatlântico: fontes e métodos. Trans-Atlantic Slave Trade Database. Disponível em: http://www.slavevoyages.org. Acesso em 15/02/2018.

Eltis, David, e Richardson, David. 2010. Atlas of the Transatlantic Slave Trade. New Haven \& Londres: Yale University Press.

Fernandes, Florestan. 2008. A Integração do Negro na Sociedade de Classes. Rio de Janeiro: Ed. Globo.

Flausino, Camila Carolina. 2006. Negócios da escravidão: tráfico interno de escravos em Mariana (1850-1886). In: Encontro Regional de História, 15. São João Del Rei. Anais... São João Del Rei: ANPUH-MG, CD-ROM, 2006.

Florentino, Manolo e Machado, Cacilda. 1998. Sobre a família escrava em plantéis ausentes do mercado de cativos: três estudos de casos (século 19). XI Encontro Nacional de Estudos Populacionais da ABEP.

Florentino, Manolo Garcia. 1997. Em costas negras: uma história do tráfico atlântico de escravos entre a África e o Rio de Janeiro. Séculos XVIII e XIX. Companhia das Letras: São Paulo.

Fragoso \& Florentino. 1987. Marcelino filho de Inocência Crioula, neto de Joana Cabinda: um estudo sobre famílias escravas em Paraíba do Sul (1835-1872). In. Estudos Econômicos 17(2): 151-173. Maio/Ago.

Furtado, Celso Monteiro. 1972. Formação econômica do Brasil. São Paulo: Cia Editora Nacional.

Góes, José Roberto e Florentino, Manolo. Morfologias da infância escrava: Rio de Janeiro, séculos XVIII e XIX" in: Manolo Florentino (Org.), Tráfico, cativeiro e liberdade (Rio de Janeiro, séculos XVII-XIX), Rio de Janeiro: Civilização Brasileira, 2005.

Góes, J.R. \& Florentino, M. 1999. Crianças escravas, crianças dos escravos. Em: Priore, M.(Org.), História das crianças no Brasil (pp. 177-191). São Paulo: Contexto.

Góes, José Roberto Pinto de. 1998. Escravos da paciência: um estudo sobre a obediência escrava no Rio de Janeiro (1790-1850), tese apresentada ao Programa de Pós-Graduação da Universidade Federal Fluminense, Niterói.

Góes, José Roberto. 1997. A paz das senzalas. Famílias escravas e tráfico atlântico, Rio de Janeiro, c. 1790 1850, Rio de Janeiro: Civilização Brasileira. 
Graham, Maria. 1956. Diário de uma viagem ao Brasil. São Paulo: Companhia Editora Nacional.

Graham, Richard. 2002. Nos tumbeiros mais uma vez? O comércio interprovincial de escravos no Brasil. Afro-Ásia, 27, 121-160.

Gutierres. 1989. O tráfico de crianças escravas para o Brasil durante o século XVIII. História, São Paulo, 120, p.59-72. jan/jul.

Hogerzeil, Simon J. and Richardson, David. 2007. Slave Purchasing Strategies and Shipboard Mortality: Dayto-Day Evidence from the Dutch African Trade, 1751-1797. The Journal of Economic History 67:160-190.

Karash, Mary C. 2000. A vida dos escravos no Rio de Janeiro, 1808-1850, São Paulo: Companhia das Letras.

Klein, Hebert. 1987. A Demografia do Tráfico Atlântico de Escravos para o Brasil. Estudos Econômicos, São Paulo 17(2): 129-149, maio/ago.

Klein, Herbert. 1989. Novas interpretações do tráfico de escravos do atlântico. R. História, São Paulo. 120: 3-25, jan/jul.

Klein, Herbert. 1971. The Internal Slave Trade in Nineteenth Century Brazil: A Study of Slave Importations into Rio de Janeiro in 1852. Hispanic American Historical Review, LI, no. 4 (Nov. 1971): 567-568

Klein, Herbert. 2002. The structure of the atlantic slave trade in the 19th century: an assessment. RFHOM, T. $89, \mathrm{~N}^{\circ} 336-337$.

Klein, In Schwarcz, Lilia Moritz e Gomes, Flávio dos Santos (Orgs.). 2018. Dicionário da escravidão e liberdade. São Paulo: Companhia das Letras.

Lara, Silvia Hunold. 1988. Campos da Violência. Escravos e senhores na capital do Rio de Janeiro, 1750-1808. Rio de Janeiro: Paz e Terra.

Luna \& Klein. 2010. Escravismo no Brasil, São Paulo: Edusp.

Machado, Maria Helena P. T. 2014. Crime e Escravidão. Edição revista e ampliada. $2^{\circ}$ ed. São Paulo: EDUSP.

Machado, Maria Helena P. T. 2010. O Plano e o Pânico. Os Movimentos Sociais na Década da Abolição. 20. ed. São Paulo: EDUSP.

Machado, Maria helena P. T. In Schwarcz, Lilia Moritz e Gomes, Flávio dos Santos (Orgs.). 2018. Dicionário da escravidão e liberdade. São Paulo: Companhia das Letras.

Mamigonian, Beatriz Gallotti e Grinberg, Keila In Schwarcz, Lilia Moritz e Gomes, Flávio dos Santos (Orgs.). 2018. Dicionário da escravidão e liberdade. São Paulo: Companhia das Letras.

Marquese, Rafael de Bivar. 2004. Feitores do corpo, missionários da mente: Senhores, letrados e o controle dos escravos nas Américas, 1660-1860. São Paulo: Companhia das Letras.

Marquese, Rafael de Bivar. 2013. Estados Unidos, Segunda Escravidão e a Economia Cafeeira do Império do Brasil. Almanack 5: 51-60.

Marquese, Rafael e Salles, Ricardo. 2016. Escravidão e capitalismo histórico no século XIX: Cuba, Brasil e Estados Unidos. Rio de Janeiro: Civilização Brasileira.

Mattos, Hebe e Grinberg, Keila In: Schwarcz, Lilia Moritz e Gomes, Flávio dos Santos (Orgs.). 2018. Dicionário da escravidão e liberdade. São Paulo: Companhia das Letras.

Mattoso, Kátia de Queirós. 2003. Ser escravo no brasil. São Paulo: Brasiliense, 3 ed.

Mattoso, Kátia de Queiroz. 1988. O Filho da escrava (em torno da Lei do Ventre Livre). Ver. Bras. De Hist. 8(16): 37-55, S. Paulo.

Milliet, Sérgio. 1982. Roteiro do Café. São Paulo: Hucitec.

Mott, M. L. B. 1979. A criança escrava na literatura de viagens. Cadernos de Pesquisa. Fundação Carlos Chagas 31: 57-68, São Paulo.

Mott, M. L. B. A. Ser mãe: a escrava em face do aborto e do infanticídio. R. História, São Paulo. 120. pp.85-96, jan/jul., 1989.

Mott, M. L. B. Neves, M. F. R. Venancio, R. P. 1988. A escravidão e a criança negra. Ciência Hoje 48, São Paulo. 
Motta, José Flávio. 1988. Família escrava: uma incursão pela historiografia, História: Questões \& Debates 9(16): 104-59.

Motta, José Flávio. 1999. Corpos escravos, vontades livres. Estrutura de posse de cativos e família escrava em um núcleo cafeeiro (Bananal, 1801-1829), São Paulo: Annablume \& FAPESP.

Motta \& Marcondes. 2000. O comércio de escravos no Vale do Paraíba Paulista: Guaratinguetá e Silveiras na década de 1870. Estudos Econômicos 30(2): 267-299, abr/jun, São Paulo.

Motta, José Flávio. 2002. A família escrava na historiografia brasileira: os últimos 25 anos. In: Eni de Mesquita Samara (org.), Historiografia brasileira em debate: "olhares, recortes e tendências" (São Paulo: Humanitas; FFLCH/USP, pp. 235-54.

Motta, José Flávio. 2012. Escravos Daqui, Dali e de Mais Além: o tráfico interno de cativos na expansão cafeeira paulista (Areias, Guaratinguetá, Constituição/Piracicaba e Casa Branca, 1861-1887). São Paulo: Alameda Casa Editorial.

Motta, José Flávio. 2015. Crianças no apogeu do tráfico interno de escravos. Piracicaba, província de São Paulo (1874-1880). História Econômica \& História de Empresas 18(2): 291-322.

Moura, Clóvis. 2004. Dicionário da Escravidão Negra no Brasil. São Paulo: EDUSP.

Nequete, Lenine. 1988. Escravos e magistrados no Segundo Reinado: aplicação da Lei n ${ }^{\circ} .040$, de 28 de setembro de 1871. Brasília: Fundação Petrônio Portela.

Parron, Tâmis. 2007. Política do tráfico negreiro: o Parlamento imperial e a reabertura do comércio de escravos na década de 1830. Estudos Afro-Asiáticos 1-2-3: 91-121.

Pinheiro, Maria Cristina Luz. 2005. O trabalho de crianças escravas na cidade de Salvador (1850- 1888). Afro-Ásia 32:159-183.

Pirola, Ricardo Figueiredo. 2011. Senzala Insurgente: mulungos, parentes e rebeldes nas fazendas de Campinas (1831). Campinas, SP. Ed. UNICAMP.

Priore, Mary del. 1999. História das crianças no Brasil. São Paulo: Ed. Contexto.

Rios, Iara Nancy Araújo. 2003. Nossa Senhora da Conceição do Coité: poder e política no século XIX. Dissertação de Mestrado em História: Universidade Federal da Bahia, Salvador.

Rocha, Cristiany Miranda. 2004. Histórias de famílias escravas: Campinas, século XIX. Campinas, SP. Ed. UNICAMP.

Rossini, Gabriel A.A. 2015. A dinâmica do tráfico interno de escravos na franja da economia cafeeira paulista (1861-1887). Tese de Doutorado apresentada ao Instituto de Economia da Universidade Estadual de Campinas. Campinas.

Salles, Ricardo. In: Schwarcz, Lilia Moritz e Gomes, Flávio dos Santos (Orgs.). 2018. Dicionário da escravidão e liberdade. São Paulo: Companhia das Letras.

Santos, Ronaldo Marcos dos. 1980. Resistência e superação do escravismo na província de São Paulo (18851888). São Paulo: IPE/USP.

Scheffer, Rafael da Cunha. 2012. Comércio de escravos do sul para o sudeste, 1850-1888: economias microrregionais, redes de negociantes e experiência cativa. Tese de Doutorado apresentada ao Instituto de Filosofia e Ciências Humanas da Universidade Estadual de Campinas. Campinas.

Simonato, Andréa Jácome. 1998. O parentesco entre os cativos no meio rural do Rio de Janeiro em 1860. População e família 1(1): 143-179.

Slenes, Robert W. 1976. The demography and economics of Brazilian slavery: 1850-1888.Tese de doutorado. Stanford University, Stanford.

Slenes, Robert W. 1987. Escravidão e família: padrões de casamento e estabilidade familiar numa comunidade escrava (Campinas, século XIX), Estudos Econômicos 17(2): 217-27.

Slenes, Robert W., Costa, Iraci Del Nero da, e Schwartz, Stuart B. 1987. A família escrava em Lorena (1801), Estudos Econômicos 17(2): 245-95. 
Slenes, Robert W. 1988. Lares negros, olhares brancos: histórias da família escrava no século XIX, Revista Brasileira de História 8(16): 189-203.

Slenes, Robert W. 1998. A formação da família escrava nas regiões de grande lavoura do Sudeste: Campinas, um caso paradigmático no século XIX, População e família 1(1): 9-82.

Slenes, Robert. 1986. Grandeza ou decadência? O mercado de escravos e a economia cafeeira da província do Rio de Janeiro, 1850-1888. In: COSTA, Iraci (org.) Brasil: história econômica e demográfica. São Paulo: Instituto de Pesquisas Econômicas, USP.

Slenes, Robert. 2004. The Brazilian Internal Slave Trade, 1850-1888: Regional Economies, Slave Experience, and the Politics of a Peculiar Market. In: Johnson, Walter (Org.) The Chattel Principle: Internal Slave Trades in the Americas. Yale University Press.

Slenes, Robert. 2010. Família escrava e trabalho. Tempo 3(6), Dezembro de 1998. SLENES, Robert. Brazil. In. Slavery in the Americas. Oxford University Press Inc. New York.

Slenes, Robert. 2011. Na Senzala, uma Flor - Esperanças e Recordações na Formação da Família Escrava. Campinas, SP: UNICAMP.

Teixeira, Heloísa Maria. 2010. Os filhos das escravas: crianças cativas e ingênuas nas propriedades de Mariana (1850-1888). Cadernos de História, Belo Horizonte 11(15), $2^{\circ}$ sem.

Teixeira, Heloísa Maria. 2002. Família escrava, sua estabilidade e reprodução em mariana 1850-1888. Afro-Ásia 28: 179-220.

Valencia Villa \& Florentino. 2016. Abolicionismo inglês e tráfico de crianças escravizadas para o Brasil, 18101850. História (São Paulo) 35. 